\title{
A Study on Evolving Digital Transformation in Indian Banking System
}

\author{
Vidya M. ${ }^{1^{*}} \&$ Shailashri V. T. ${ }^{2}$ \\ ${ }^{1}$ Research Scholar, College of Management \& Commerce, Srinivas University, Mangalore, \\ India. \\ Orcid ID: 0000-0002-8953-6017, E-mail: vidya.ghanshyam@gmail.com \\ ${ }^{2}$ Research Professor, College of Management and Commerce, Srinivas University, \\ Mangalore, India. \\ Orcid ID:0000-0002-1684-238X, E-mail: shailashrivt@gmail.com
}

Area of the Paper: Business Management.

Type of the Paper: Research Case Study.

Type of Review: Peer Reviewed as per $|\mathrm{C}| \mathrm{O}|\mathrm{P}| \mathrm{E} \mid$ guidance.

Indexed In: OpenAIRE.

DOI: http://doi.org/10.5281/zenodo.4781901

Google Scholar Citation: $\underline{\text { IJCSBE }}$

\section{How to Cite this Paper:}

Vidya M. \& Shailashri V. T. (2021). A Study on Evolving Digital Transformation in Indian Banking System. International Journal of Case Studies in Business, IT, and Education (IJCSBE), 5(1), 116-130. DOI: http://doi.org/10.5281/zenodo.4781901.

International Journal of Case Studies in Business, IT and Education (IJCSBE)

A Refereed International Journal of Srinivas University, India.

Crossref DOI : $\underline{\text { https://doi.org/10.47992/IJCSBE.2581.6942.0104 }}$

(C) With Authors.

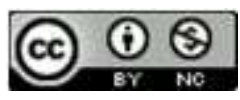

This work is licensed under a Creative Commons Attribution Non-Commercial 4.0 International License subject to proper citation to the publication source of the work.

Disclaimer: The scholarly papers as reviewed and published by the Srinivas Publications (S.P.), India are the views and opinions of their respective authors and are not the views or opinions of the S.P. The S.P. disclaims of any harm or loss caused due to the published content to any party. 


\title{
A Study on Evolving Digital Transformation in Indian Banking System
}

\author{
Vidya M. ${ }^{1^{*}}$ \& Shailashri V. T. ${ }^{2}$ \\ ${ }^{1}$ Research Scholar, College of Management \& Commerce, Srinivas University, Mangalore, \\ India. \\ Orcid ID: 0000-0002-8953-6017, E-mail: vidya.ghanshyam@gmail.com \\ ${ }^{2}$ Research Professor, College of Management and Commerce, Srinivas University, \\ Mangalore, India. \\ Orcid ID:0000-0002-1684-238X, E-Mail: shailashrivt@gmail.com
}

\begin{abstract}
Purpose: Industry analysis gives a broad idea of industry in terms of its objectives, resources as inputs and functions, products \&services as output. In this paper, we have studied various electronic payment systems practiced by the banking industry like card payments NEFT, RTGS, IMPS, and UPI. Analysis has been done on the value \&volume, growth of these digital payments over the last 5years. A comprehensive analysis of the evolving digital payments using the $A B C D$ model is performed.

Design/methodology /Approach: This industry analysis is the conceptual research case study. Analysis of digital payment is done using ABCD analysis. Data and information have been collected from various online open access sources using Google scholar, ResearchGate, RBI, GOI reports \& journals.
\end{abstract}

Finding/ Result: Based on ABCD analysis the advantages and benefits of the digital payment mechanism are more prominent than constraints and disadvantages. It is found that digital Epayments are very useful in the current scenario.

Originality value: This paper analyses and interprets the digital payment system of the banking industry in terms of its current status and future opportunities. Based on findings, recommendations are presented.

Paper type: A Research case study paper on Evolving digital payment systems of the banking industry.

Keywords: Banking industry, Electronic payment system, NEFT, IMPS, RTGS, UPI, ABCD analysis

\section{INTRODUCTION :}

In the last 10 years Indian economy has witnessed as one of the fastest-growing economies [1]. Over time, industries started adapting themselves to the current business conditions. The same level of development is seen in respect of the banking industry. Banks constitute one of the earliest financial institutions serving the economy for a long time. Banks during their initial days acted as a custodian where customers can deposit their valuables under safe custody. Banks today have transformed themselves into digital entities offering a range of financial products and services to meet customer demand. The rapid pace of economic growth has led to significant demand in both the volume and complexity of banking functions. Therefore, the role of banks also expanded at a speedier pace. Recently the Indian banking industry has witnessed the rollout of innovative payment systems and small finance banks. The innovative new measures of RBI are helping the Banking industry to restructure itself.

\section{REVIEW OF LITERATURE ON RELATED WORK :}

Table 1 shows the related work undertaken in the field of digital banking between 2015-2019. The review work shows that the digitalization of payments has benefited the customers, employees as well as the financial sector of the economy. It is understood that digitalization has become extremely important to compete with the cashless global economy. 
Table 1: Review of digital transaction \& their focus.

\begin{tabular}{|c|c|c|c|}
\hline Sl. No & Theory & Focus & References \\
\hline 1 & $\begin{array}{l}\text { Digital transactions provide the } \\
\text { opportunity to handle any kind of banking } \\
\text { transactions that are safer\& secure. }\end{array}$ & $\begin{array}{l}\text { Understand the various } \\
\text { benefits related to } \\
\text { digital transactions. }\end{array}$ & $\begin{array}{l}\text { Srikanth Carandas } \\
\& \text { Nitesh Paunch } \\
\text { (2017). [2] }\end{array}$ \\
\hline 2 & $\begin{array}{l}\text { Cashless transactions contributing towards } \\
\text { efficiency and convenience. }\end{array}$ & $\begin{array}{l}\text { Availability of various } \\
\text { payment instruments } \\
\text { which can be used by } \\
\text { the people \& their } \\
\text { benefits. }\end{array}$ & $\begin{array}{l}\text { Shilpa Bhimrao } \\
\text { Gaonkar } \\
(2018) .[3]\end{array}$ \\
\hline 3 & $\begin{array}{l}\text { Demonetization had a significant impact } \\
\text { on digital payments which are visible in } \\
\text { RTGS \& mobile transactions. }\end{array}$ & $\begin{array}{l}\text { Assessing how } \\
\text { demonetization } \\
\text { impacted digital } \\
\text { payment in India. }\end{array}$ & $\begin{array}{l}\text { Dinesh T.M., } \\
\text { Kiran Kumar } \\
\text { Reddy (2018). [4] }\end{array}$ \\
\hline 4 & $\begin{array}{l}\text { Electronic transactions have increased due } \\
\text { to the realization by the Indian population } \\
\text { about the voluminous merits offered by } \\
\text { popular mode of payments such as credit\& } \\
\text { debit cards, net banking \& e-wallets by the } \\
\text { Indian population. }\end{array}$ & $\begin{array}{l}\text { the UPI_BHIM is } \\
\text { offering services of } \\
\text { electronic payments to } \\
\text { the customers. }\end{array}$ & $\begin{array}{l}\text { Rakesh K., Suresh } \\
\text { Kumar, Dr. S. } \\
\text { Sateesh Kumar } \\
\text { (2018). [5] }\end{array}$ \\
\hline 5 & $\begin{array}{l}\text { Digitization of the economy has become } \\
\text { extremely important\& unavoidable to keep } \\
\text { pace with the fast-growing cashless global } \\
\text { economy. }\end{array}$ & $\begin{array}{l}\text { The impact of factors } \\
\text { on the attitude of } \\
\text { consumers. }\end{array}$ & $\begin{array}{l}\text { Shilza, Madhulika, } \\
\text { P. Sarkar (2019). } \\
\text { [6] }\end{array}$ \\
\hline 6 & $\begin{array}{l}\text { Debit cards are more preferred by the } \\
\text { customers when compared with Credit } \\
\text { cards at ATMs. }\end{array}$ & $\begin{array}{l}\text { The RBI has made } \\
\text { headway in directing } \\
\text { the banks to cashless } \\
\text { transactions. }\end{array}$ & $\begin{array}{l}\text { Pardhasaradhi } \\
\text { Madasu (2015). [7] }\end{array}$ \\
\hline 7 & $\begin{array}{l}\text { The Developing country's economic } \\
\text { growth \& development has shown } \\
\text { advancement by instilling a cashless } \\
\text { payment system. }\end{array}$ & $\begin{array}{l}\text { Studying the cashless } \\
\text { payment system helps } \\
\text { in imparting a cashless } \\
\text { economy. }\end{array}$ & $\begin{array}{l}\text { N. Kumari \& J. } \\
\text { Khanna (2017). [8] }\end{array}$ \\
\hline
\end{tabular}

\section{OBJECTIVES :}

(1) To understand the transformation of the Indian Banking Sector.

(2) To access \& highlight the major players in the Indian Banking Sector.

(3) To study evolving digital payments used in banking services.

(4) To analyze the trend of digital innovation in the Banking Sector through ABCD analysis.

\section{RESEARCH METHODOLOGY:}

The study is Conceptual. RBI reports \& government websites, journals have been referred. Analysis of digital payments has been done using the ABCD framework.

\section{AN OUTLINE OF THE TRANSFORMATION OF THE INDIAN BANKING SECTOR :}

The growth of the Indian banking industry can be broadly classified into three distinct Eras. Preindependence (1786 - 1947) and Post-independence (1947 - 1991), Post Liberalization (1991 onwards) (figures 1 to 3 ). 


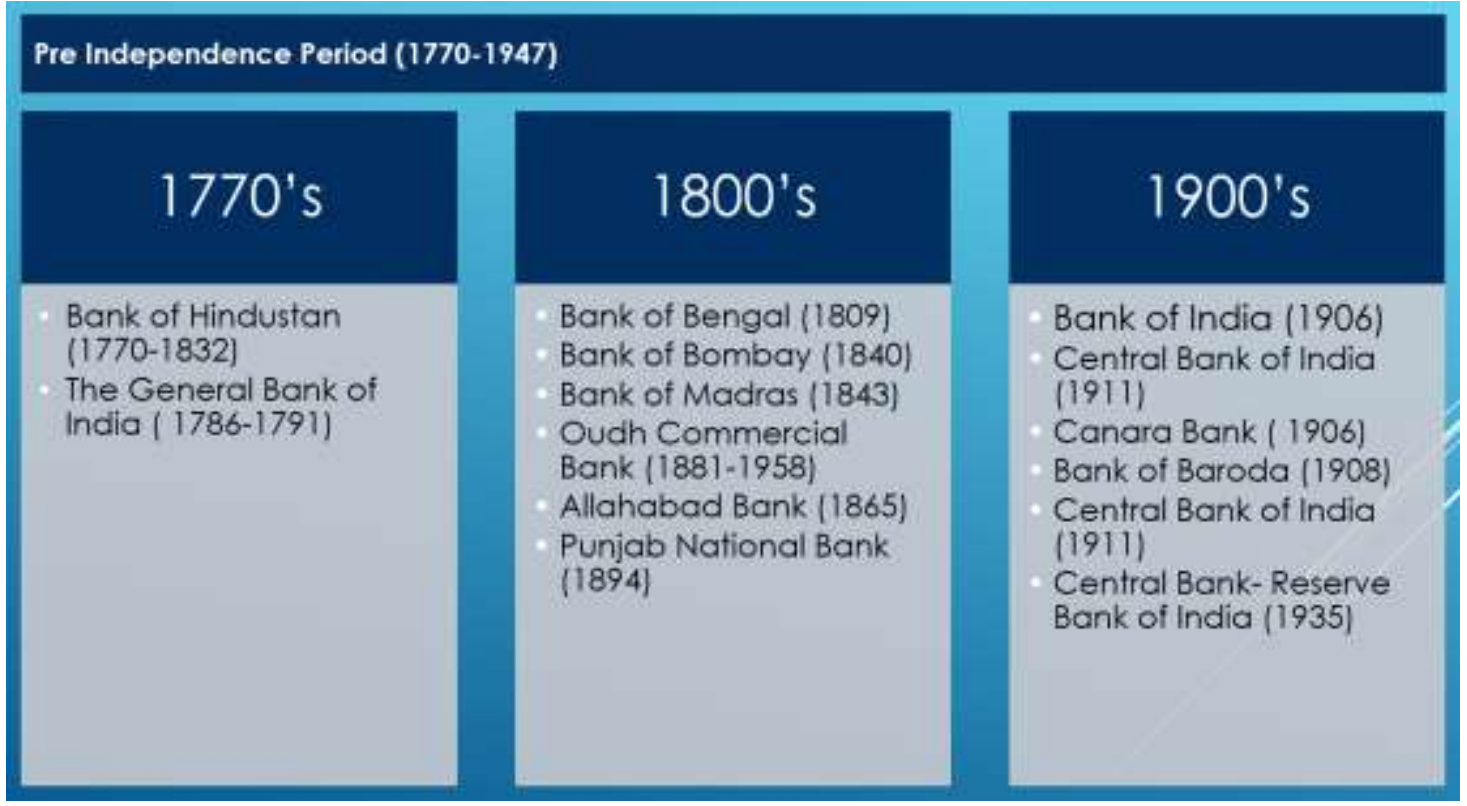

Fig. 1: Banks of Pre-independence period (1786 - 1947)

The roots of the Indian banking industry are found with the formation of the Bank of Bengal in Calcutta (now Kolkata) in 1786. At the beginning of the 20th Century the Bank of Bombay, The Bank of Bengal, and The Bank of Madras have taken the lead as presidency banks to control and manage the Indian banking business, which in 1921 merged as the Imperial Bank of India. Reserve Bank of India was established in 1935 as an apex banking institution which is known as the Central bank of a nation.

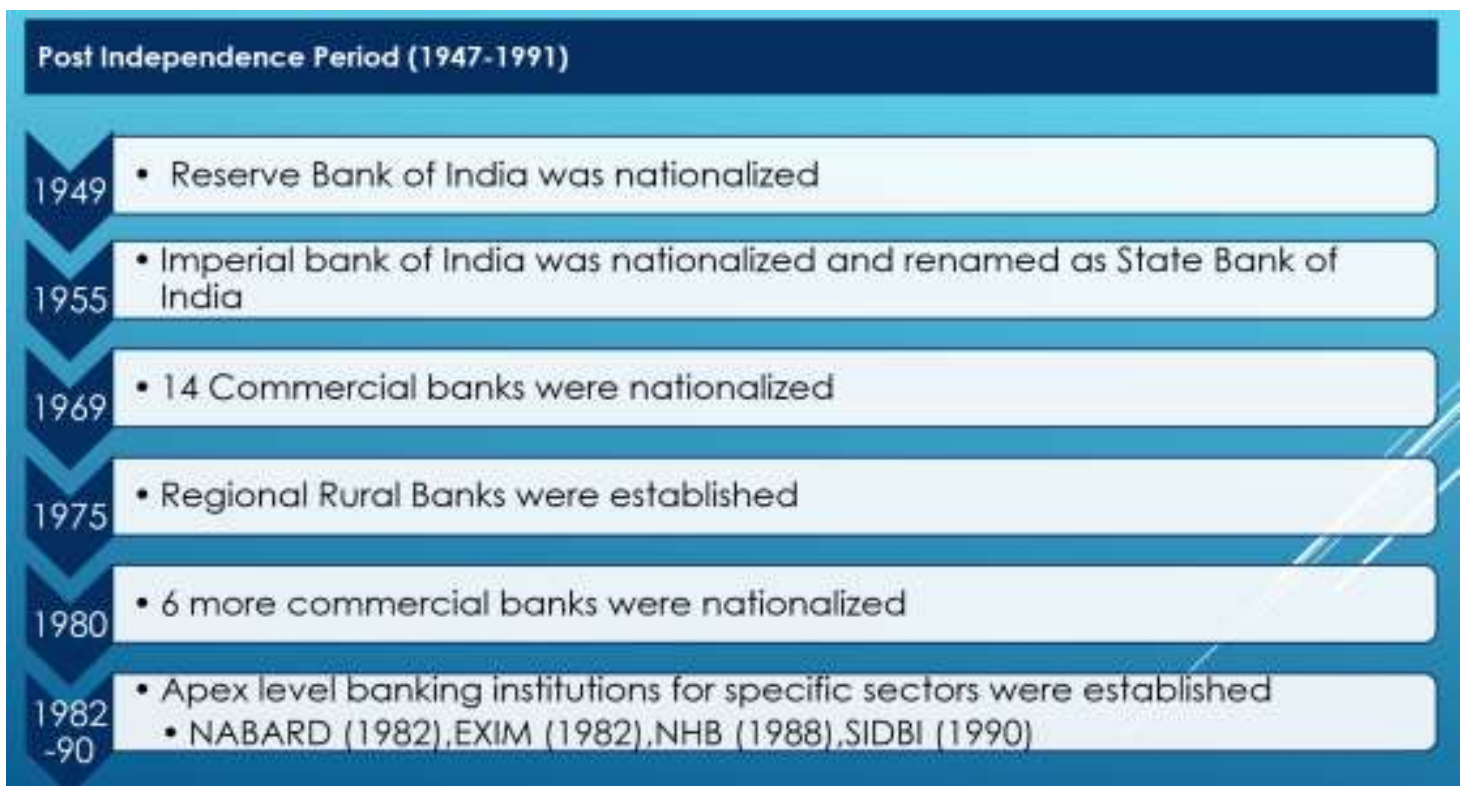

Fig. 2: Banks of Post-independence Period (1947 - 1991)

Imperial Bank of India was nationalized and became the State Bank of India. The other 14 banks have been nationalized on $19^{\text {th }}$ July 1969 [9]. In 1980 Six more commercial banks were nationalized. Apex level banking institutions for specific sectors like Agriculture, Export Import, Small scale industries were established in the 1980s leading to economic growth. 


\section{International Journal of Case Studies in Business, IT, and Education SRINIVAS (IJCSBE), ISSN: 2581-6942, Vol. 5, No. 1, May 2021

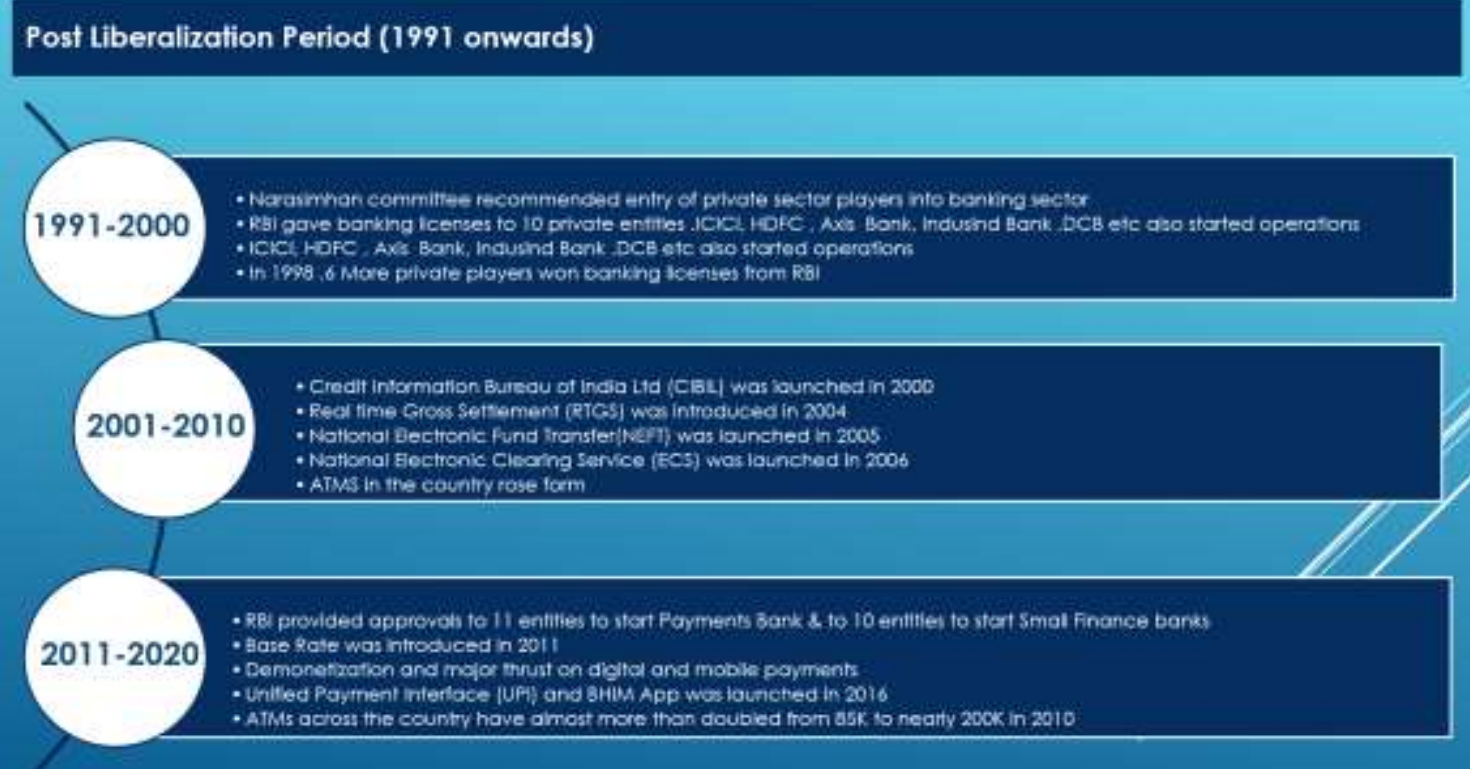

Fig. 3: Transformation of Banks Post Liberalization (1991 onwards)

The liberalization of economic policies in 1991 during the post-liberalization period given entry to private sector business units. Simultaneously changes started in the banking sector also by entry of private sector players. RBI gave license to 10 private sector banks to establish like ICICI bank, HDFC bank, Axis bank, etc. they started their regular banking operations along competing with public sector bank. Major reforms in banking services started during the second decade of post-liberalization from 2000 onwards. New payments system such as RTGS, ECS, NEFT was launched and even ATMs were started to function for providing convenient services to customers. The third decade started from 2010 onwards, which has seen tremendous growth in the field of banking. RBI provided approval to 11 entities to start payment banks and to 10 entities to start small finance banks. Most digitalized service unified payment interface (UPI) and BHIM app were launched in 2016 which has brought all the services to the doorstep of a customer. ATM establishment across the country has almost doubled from $85 \mathrm{~K}$ to $200 \mathrm{k}$ in 2010 which shows the stable growth of the Indian economy and simultaneously keeps introducing new evolving payments in the form of digital banking to meet the expectations of the customers.

\section{MAJOR PLAYERS OF THE INDIAN BANKING SECTOR :}

Presently in India, we have 80 Scheduled Commercial Banks which consists of all types of banks like 12 Public sector banks,22 Private banks, and 46 Foreign Banks. Around 75\% of the total assets of the banking industry are under the control of Public sector banks. So, it plays a major role in providing banking services with private sector banks \& foreign banks holding $18.2 \%$ \& $6.5 \%$ respectively. Based on the size and total assets few major players contributing towards the growth of the Indian Banking industry are State bank of India, Bank of Baroda, Punjab National Bank, Canara Bank, ICICI Bank, HDFC Bank, Standard Charted Bank, HSBC Bank, ABN AMRO Bank and so on. An overview of the First three largest banks in public sectors and private sectors are given below (figure 4).

6.1 Public Sector Banks: These are banks in which more than $50 \%$ stake is held by the government. Currently, 12 banks are functioning under the public sector because of the merger of many banks. These banks are classified into nationalized banks and State Bank of India \& its subsidiaries. State Bank of India is the largest bank among Public sector banks followed by Bank of Baroda and Punjab National Bank. 


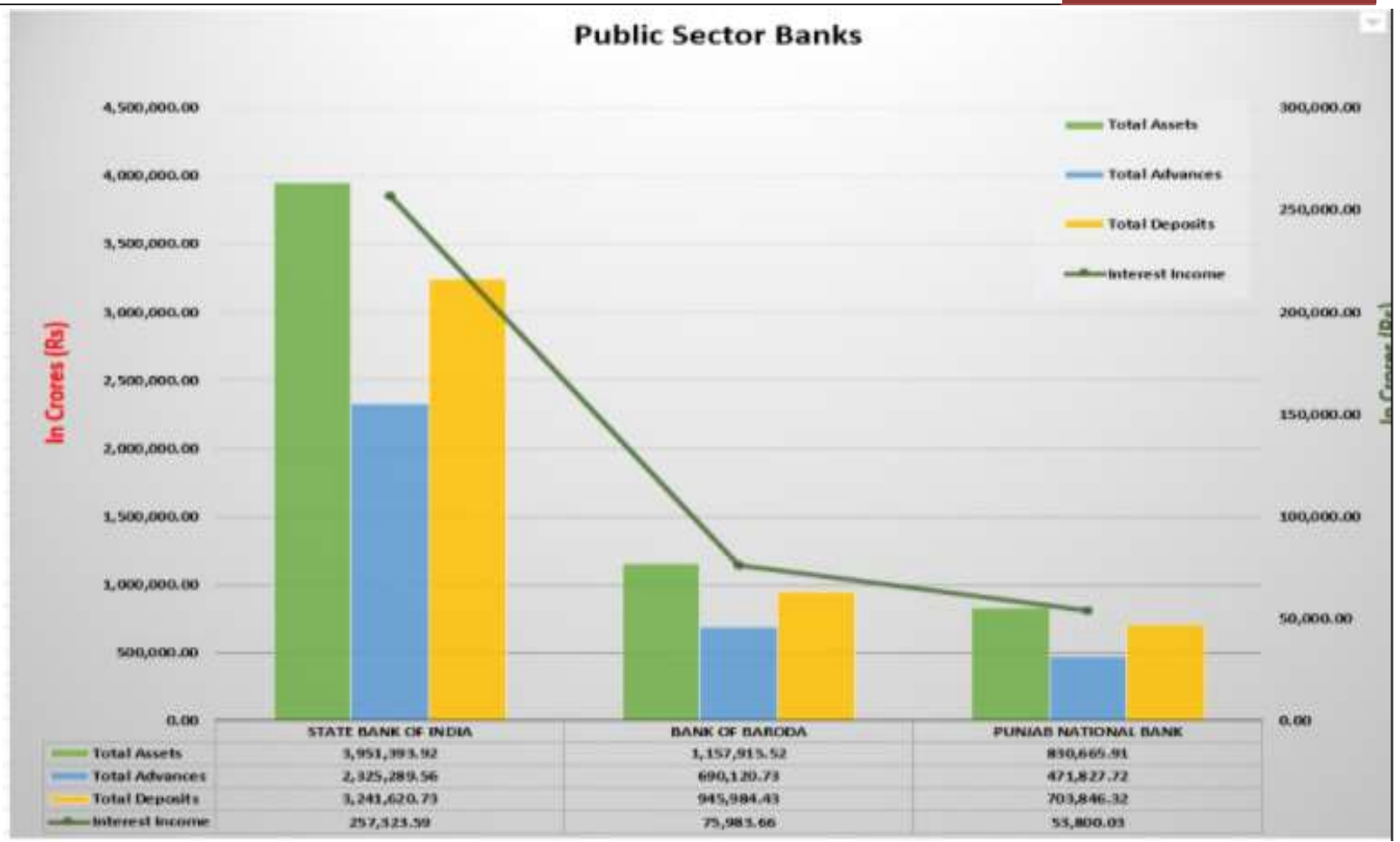

Data Source: Annual reports of SBI, PNB, and Bank of Baroda

Fig. 4: Comparative analysis of Assets, Advances, Deposits, and Interest Income of major players in the public sector.

State Bank of India: One of the largest banking and financial institutions serving India with its seven subsidiaries. In addition to banking, it also provides other services like a mutual fund, SBI fast tag, NRI services, credit cards, insurance, trading in a security, and pension fund management, and occupying a major role in the money market. Having more the 16000 branches in India is considered as the largest branch network Bank. It also started with innovative banking service using technology like Mobile Banking, Internet Banking, ATM, RTGS, IMPS, and other services which is at the convenience of customers. The Net Interest Income of the bank has recorded tremendous growth. The Net Interest Income has shown remarkable growth from Rs. 163998.30 crores in 2015-16 to Rs. 257323.09 crores in 2019-20 as a result of interest income on advances and investments. Bank's total assets have increased from Rs. 2357617.55 crores in 2015-16 to Rs.3927631.24 crores as at end of March 2020 showing tremendous growth in its performance. The deposits have shown an upward trend from RS.1730722.44 crores in 2015-16 to Rs.3241620.73 crores in 2019-20. The advances of the bank registered a growth from 2015-16 to 2019-20 as a mark of growth prospect.

Bank of Baroda: India's second-largest public sector bank is the Bank of Baroda. It was founded in July 1908 \& later the government has nationalized it in July 1969. In September 2018, the major reform was announced by the government of India to the merge Bank of Baroda, Vijaya Bank, and Dena Bank to create the second-largest lender in the country. After a merger, its operating profit has increased and NPA reduced. The bank also embarked on a journey of transformation with a focus on digitization to build a digital interface that enables the bank to sustain its competitive advantage. Currently, its service concentration is on paperless approvals and flexibility to staff to provide work from home options to reduce overall expenses. To promote digitalization banks came out with digital modes of payment like Mobile Banking, Internet Banking, ATM banking, etc. When we analyze the trend of growth and development of the bank for the past 5years deposits have raised from Rs.574037.87 crores in 2016 to Rs. 945984.43 crores in 2020. Advances have also shown an upward trend. Total assets have registered a growth from Rs.671376.48 crores to Rs. 1157915.52 crores in 2020. Net interest income has also shown an upward trend of Rs. 44061.28 crores from 2016 to Rs. 75983.66 crores in 2020.

Punjab National Bank: The Bank occupies the third position under public sector bank. It is formed in 
1894 both in terms of banking and its network. It has over 180 million customers and it has more than 11000 branches \& 13000 ATM branches. It has been merged with The United Bank of India and the Oriental Bank of Commerce. It has a banking subsidiary in foreign countries also. Apart from banking services it provides merchant banking, mutual fund, depository services, cash management services, NRI services, and so on. Overall analysis shows that the net interest income of the bank has certified a growth from Rs.47424.35 crores in 2015-16 to Rs.53800.33 crores in 2019-20 as a result of new advances and investments. The Banking assets have been increased fromRs.667390.46 crores in 201516 to Rs. 830665.91crores in 2019-20. The overall deposits have been increased from Rs.553051.13crores in 2015-16 to Rs.703846.32 crores in 2019-20. Banks are investing in technology to automate business operations thereby improve efficiency, reducing transaction costs, and manage risk factors. The digital payments services are made available with new technology such as PNB Mpassbook, BHIMPNB, PNB Mobi ease, etc. Most recently an app called 'PNB ONE' was introduced which is unifying mobile apps under one app. So that with a single platform multiple services reach customers.

6.2 Private Sector Banks: Private sector banks are also occupying a pivotal role in the economic development of the nation. These private sector banks are either run by individuals or a group of partners by contributing their share. There are 22 private sector banks currently operating in India, Eg.: HDFC, ICICI, IndusInd bank, Federal bank, Kottak Mahindra bank, and so on. HDFC Bank is the largest private sector bank and occupies a major role in respect of market capitalization. ICICI Bank and Axis Bank is in the second \& third position (figure 5).

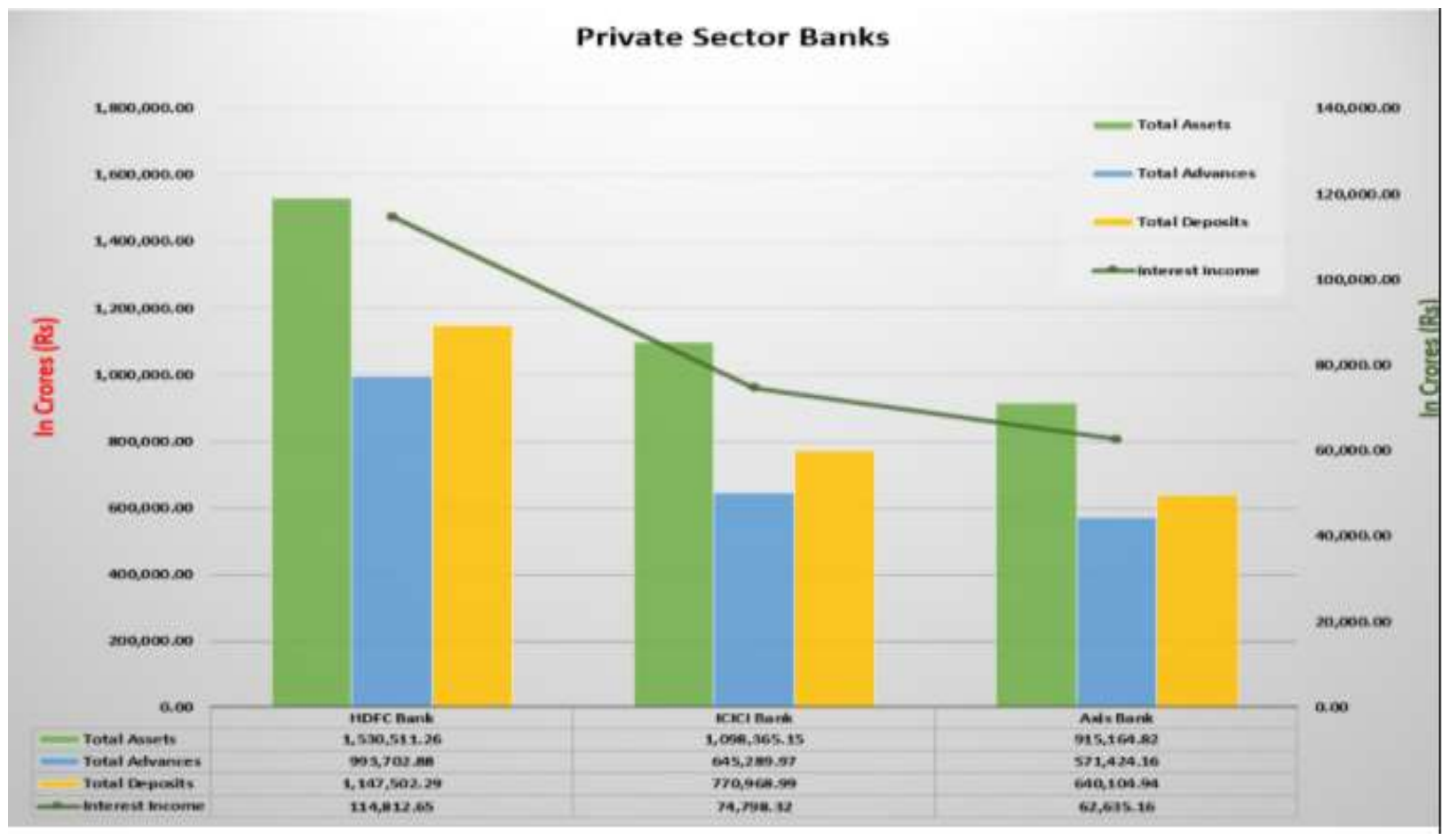

Data Source: Annual reports of HDFC Bank, ICICI Bank, Axis Bank

Fig. 5: Comparative analysis of Assets, Advances, Deposits and Interest Income of major players in Private sector Banks

HDFC Bank: It is a subsidiary of the Housing development corporation of India and started operating as a bank in 1994. It is the largest bank in the Indian private sector by assets and market capitalization. The Bank performs several functions including wholesale banking, treasury, retail banking services, credit cards, and digital products like payzapp \& smart buy. The bank has shown an upward trend in interest from advances raised to $63.2 \%$ and income from investment to $20.9 \%$. Net profit has increased from $20.4 \%$ to $24.6 \%$ in $2019-20$. Total assets have increased from Rs.708845.57 crores in 2015-16 to Rs.1530511.26 crores in 2019-20. The deposit intake has raised from Rs.546424.19 to Rs.1147502.29 crores in 2019-20. Total advances have shown an upward trend from Rs.464593.96 crores in 2015-16 
to Rs.993702.88 crores in 2019-20. It has started digitization in 2017 thereby empowering virtual banking to engage with customers through technology. Various digital innovations like my account my choice, cordless withdrawal, WhatsApp banking smart slips have introduced in 2019.

ICICI Bank: The Industrial Credit and investment corporation of India established a bank called ICICI Bank to provide banking services to its customers. It has started operating as Multinational banking providing inbound and outsource services \& financial services company. It provides an ambit of services both to corporates and customers through a manual and digital mode of services. Apart from banking services other areas like insurance, investment banking, venture capital, asset management, NRI services, foreign exchange services the bank is playing a major role. The analysis of performance shows that deposits have gone up to Rs.10983365.15 crores in 2019-20 while compared with deposits of Rs.421425.71 crores in 2015-16. Total advances have raised from Rs.435263.94 crores during 201516 to Rs.645289.97 crores during 2019-20. Total assets count has grown up from Rs. 720695.10 crores in 2015-16 to Rs. 1098365.15 crores in 2019-20. Net interest income has raised from Rs52739.43 crores in 2015-16 to Rs 74798 crores in 2019-20.

AXIS Bank: The third-largest private bank is AXIS bank offering various streams of financial services for personal \& corporate banking. It was started in December 1993 as UTI bank and in 2003 it is renamed AXIS Bank. The bank reported net profit of 1627crores for the year ended March 2020. The net interest income raised by $16 \%$ to Rs.62635.16 crores in FY2020 from Rs.40988.04 crores in FY 2016. The deposits have grown from Rs.357967.56 crores in 2015-16 to Rs.770968.99 crores in 201920. The assets have been showing an increasing trend from Rs.525467.62 crores in 2015-16 to Rs.915164.82 crores in 2019-20. The overall advances intake has improved from Rs.338773.72 crores in 2015-16 to Rs571424.16 crores in 2019-20. It is the first Indian bank to introduce a dedicated innovation lab in the country. The bank has introduced self-service kiosks, Aadhar based customer services, and automation to match the current digital drive of the banking industry.

The comparative analysis of public sector banks and private sector Banks in the above figures show that total assets of Public sector Banks are higher than Private sector Banks due to their large network of branches, large consumer base, and long-term stable establishment. Total advances of Public sector Banks are also higher than Private Banks due to reasonable interest rates. There is tremendous growth in total deposits of Public sector Banks compared to Private Banks as they have the largest branch network in small cities, semi-urban apart from metropolitan cities So consists of more customers. whereas private banks are mostly located in urban cities which limits the deposit intake of banks. Total interest income has also shown an upward trend compared to private sector banks due to higher interest from investments and advances.

\section{DIGITAL PAYMENTS SYSTEMS USED IN BANKING SERVICE :}

Any kind of transfer of funds made by an individual through instruction or order to a bank to make Payment or credit the account by using electronic means is known as digital payments. It is monitored under the payment and settlement act. It includes debit cards, credit cards, point of sale, direct withdrawal or deposit, mobile payments, net payments, etc. The Indian banking sector has done rapid strides to meet the competitive business environment. Technological transformation has become an indispensable part of the reform process in the banking sector [10-13]. To compete in an economy and to survive banks started adapting themselves to digital innovations. So digital payments have started in 2017. Both volumes, as well as the value of the payment mechanism, have increased to a larger extent and new additions are also happening in the digital field to provide an easy payment method to customers. The most important digital payments prevailing in the current scenario are RTGS, NEFT, UPI, AEPS, IMPS, digital wallets [14]. Key drivers of digital payments in the volume segment are debit cards and IMPS. Slowly the UPI also started as the key driver in the volume segment. In terms of value, the key contributors are Real Time Gross Settlement and National Electronic Fund Transfer system.

7.1 NEFT: RBI has started a new payment system in November 2005 intending to provide a new online payment mechanism to the customers which are recognized as National Electronic Fund Transfer system. This facility is given to the customers in India having NEFT-enabled bank accounts. It helps to transfer funds between two on a one-to-one basis. But the condition is both the sender and receiver branches must be NEFT enabled. It is available on all days of the year and equal to real-time funds transfer to the beneficiary account by using the internet and mobile banking facility offered by the bank. 
As per RBI guidelines, no charges will be levied on member banks for NEFT transactions.

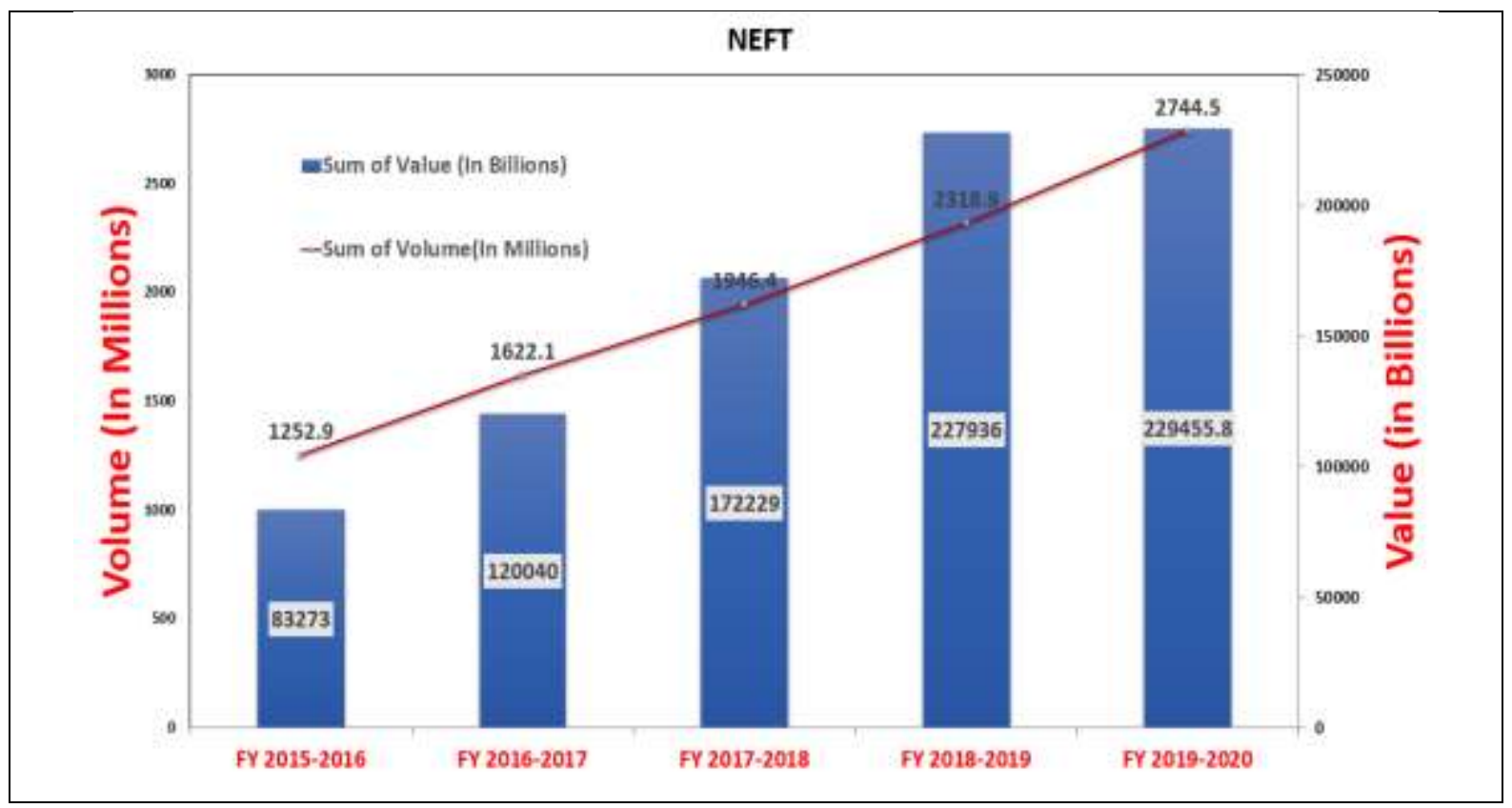

Data Source: RBI Payment System Indicators - Payment \& Settlement System Statistics

Fig. 6: NEFT Volume and Value

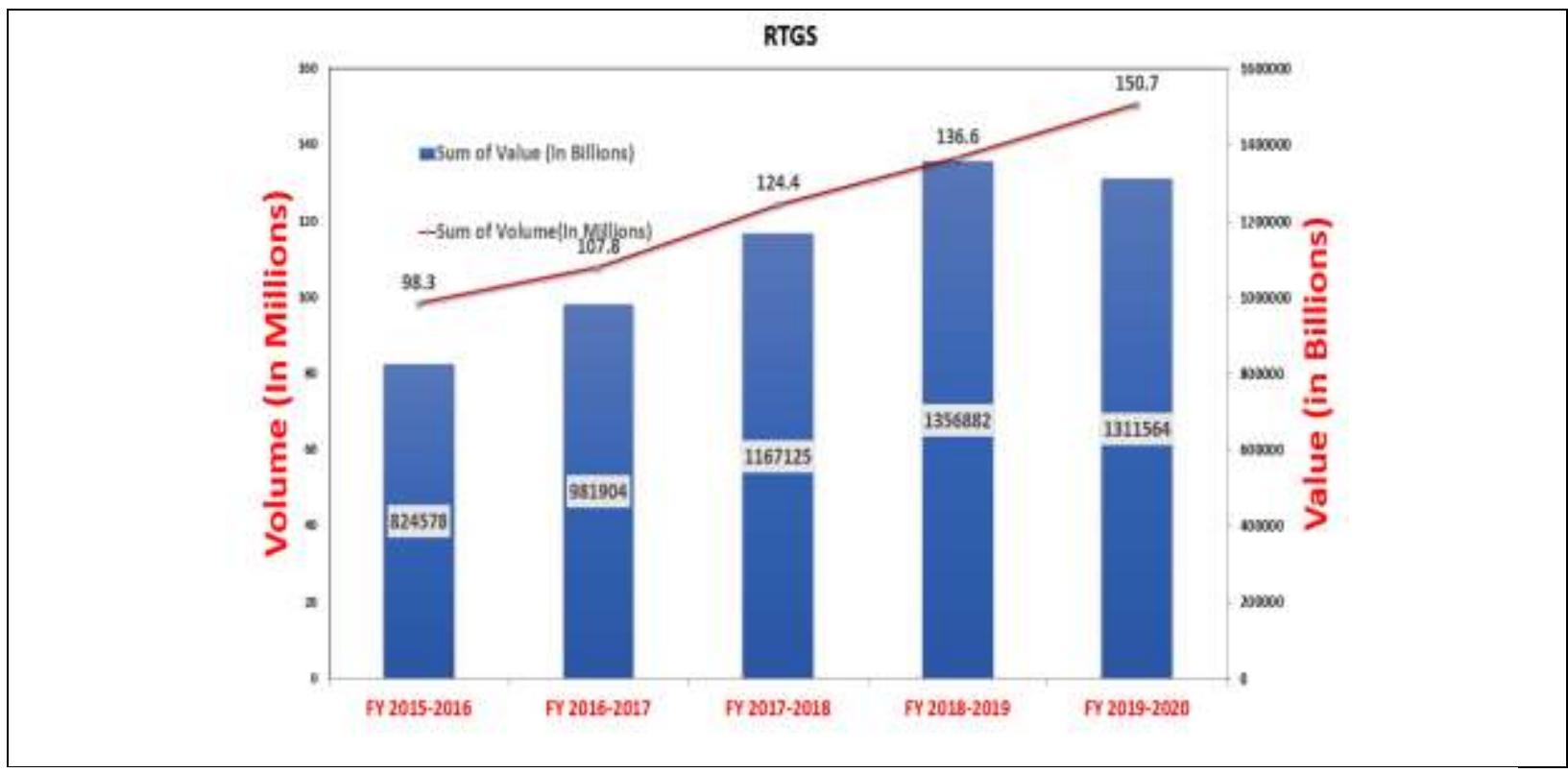

Data Source: RBI Payment System Indicators - Payment \& Settlement System Statistics

Fig. 7: RTGS Volume and Value

NEFT was earlier not available round the clock. Starting from December 2019, NEFT is now available 24/7. All the days in a year including public holidays fund transfer facility is made available for customer convenience. The total value of NEFT has shown a strong rise at a CAGR of $22.47 \%$ in five years from 2015-2020. In terms of volume, NEFT has shown an advancement from 1252.9 million in FY 2015-2016 to 2744.5 million in FY 2019-2020, with a CAGR of 16.98\% (figure 6).

7.2 RTGS: A specialized fund transfer system is introduced for the transfer of money which is known as the Real-Time Gross Settlement system. Individually an order-by-order basis fund transfer will be done by a real-time settlement of funds. so, processing will be done at the time when the fund is received. A gross settlement means fund transfer is done individually, which is final and irrevocable. 
With effect from Dec14,2020 RTGS is available 24x7 throughout the year.

RTGS were earlier not available round the clock. Starting from December 2020, RTGS is now available all the days of the year including public holidays. Service is available on a 24/7 basis. RTGS usage (in value terms) in the last five years has shown a CAGR of 9.73\% from 2015 to 20120. In terms of volumes, RTGS has shown stable growth from 98.3 million in FY 2015-2016 to 150.7 million in FY 2019-2020, with a CAGR of $8.92 \%$. The average ticket size of an RTGS transaction is 57.96 lakhs making it a truly large payment system (figure 7).

7.3 Debit Cards: It is a payment card by using this money will be directly deducted from a customer's account to pay for the purchases. So, it is one of the plastic payment systems that is linked to the customer checking account. It eliminates carrying physical checks to make purchases more directly. It has control over the usage of the amount available in the account and thereby protects the user from the default position. Some cards offer reward programs to the customers. There are three different types of debit card processing pin debit, signature debit, and contactless debit. These cards can be used for withdrawals and make payment for various purchases subject to a limit to the amount exist in the account. E.g.: online purchase, car rentals, hotel or airline reservations, etc.

Debit Cards value has increased at a CAGR of $38.33 \%$ from 2015 to 20120 . The volume trend of Debit Cards has shown strong growth from 1173.5 million in FY 2015-2016 to 5123.9 million in FY 20192020 , with a CAGR of $34.28 \%$ (figure 8).

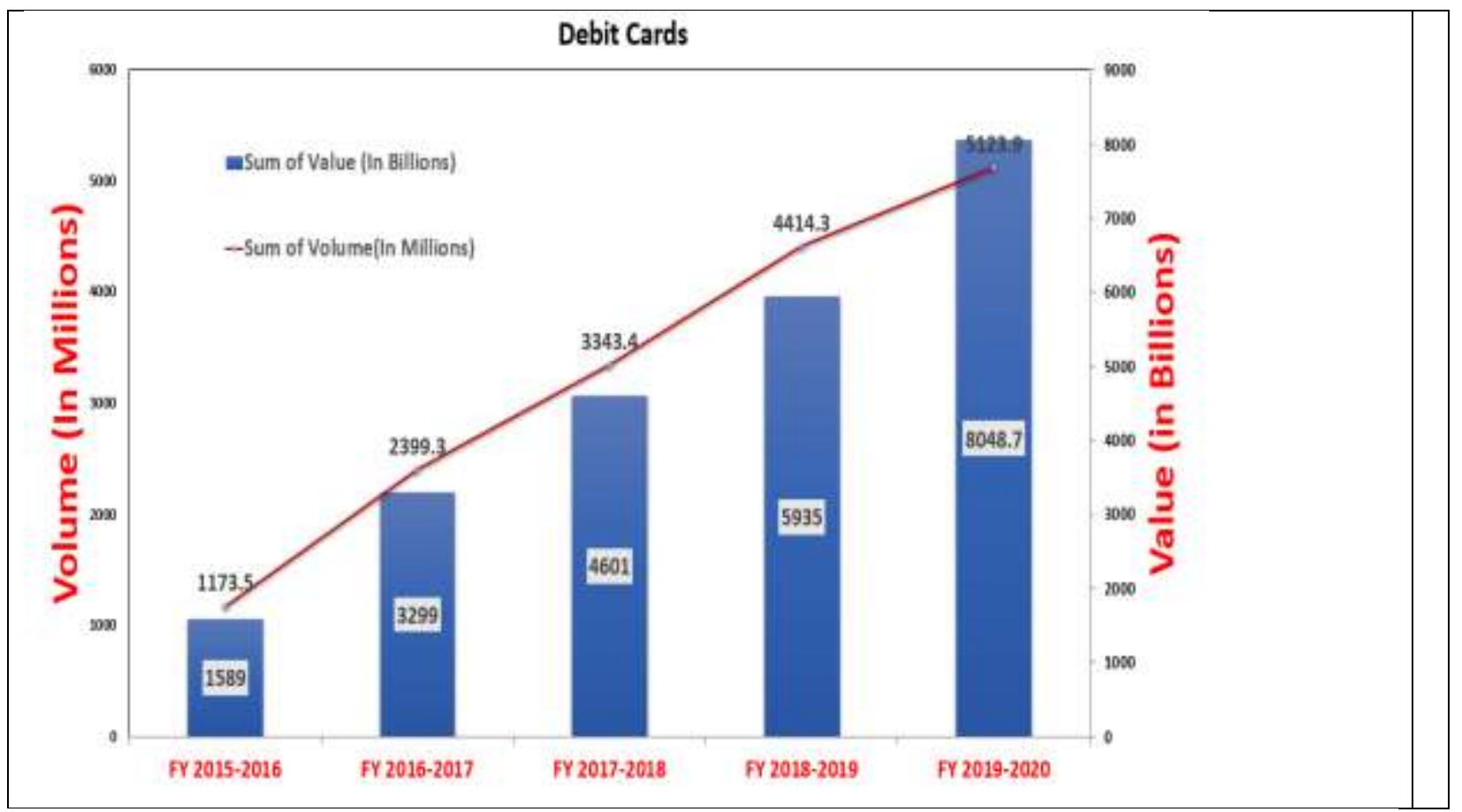

Data Source: RBI Payment System Indicators - Payment \& Settlement System Statistics

Fig. 8: Debit Cards Volume and Value

7.4 Credit Cards: It is the most common mode of electronic payment system where customers can use the card for making various types of online as well as offline payments where banks will pay on behalf of the customer and within a given time customer need to make the payments. One of the benefits of using a credit card is customer can use the cash more than in the credit of his account. There are five key parties the buyer, the merchant, the acquirer, the issuer, and the network. Its primary role is to manage payment transactions such s operations and clearing. Visa \& master cards are the largest global brands offer credit card which is accepted throughout the world. In ATM Most of the credit cards can be used to withdraw money, but charges will be levied on advances. Credit card online payment can be done through plain credit cards, encrypted credit cards, and third-party verification. 


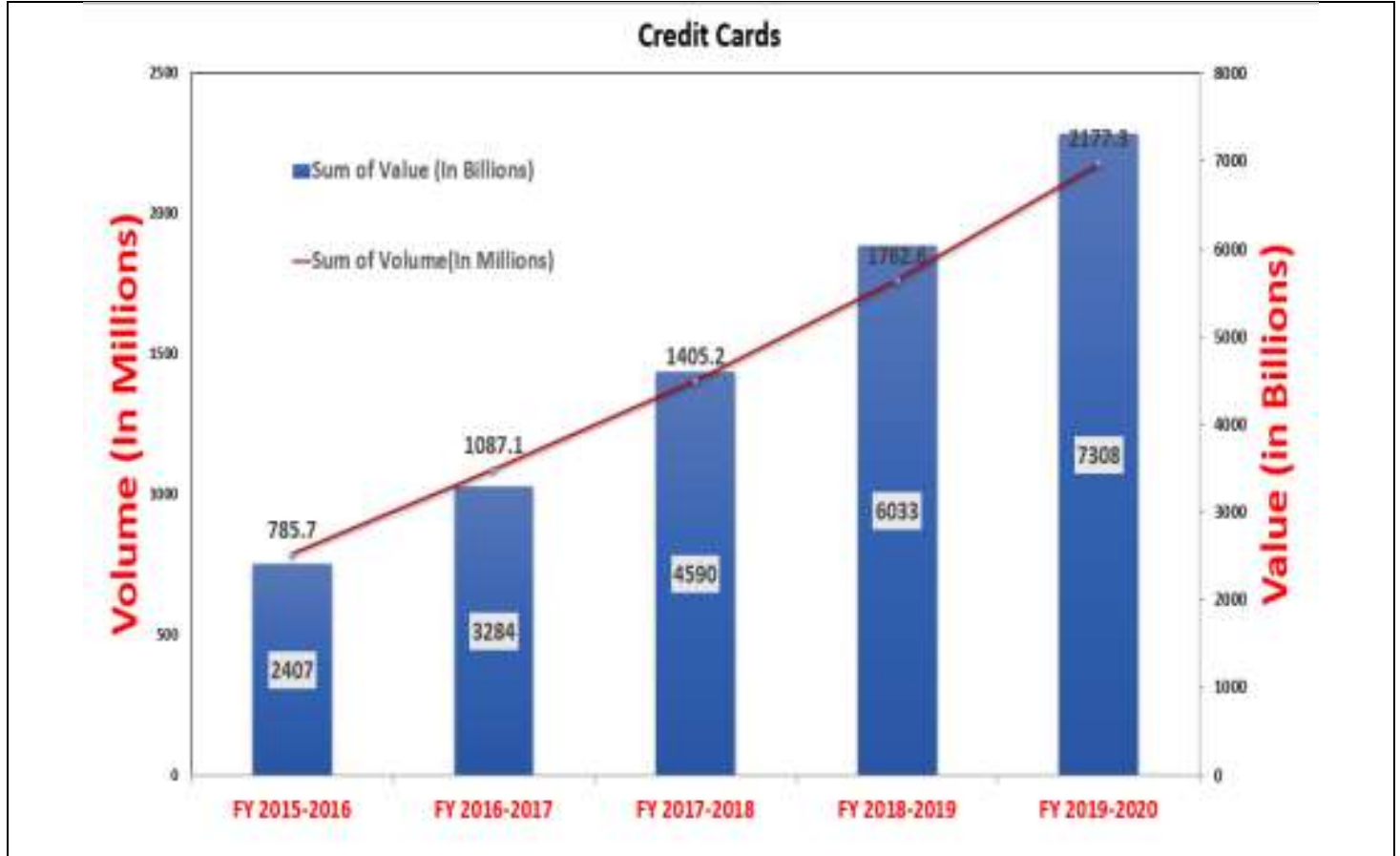

Data Source: RBI Payment System Indicators - Payment \& Settlement System Statistics

Fig. 9: Credit Cards Volume and Value

Credit Cards usage (in value terms) in the past 5 years has shown a strong rise at a CAGR of $24.87 \%$. The volumes have also shown advancement from 785.7 million in FY 2015-2016 to 2177.3 million in FY 2019-2020, with a CAGR of 22.61\% (figure 9).

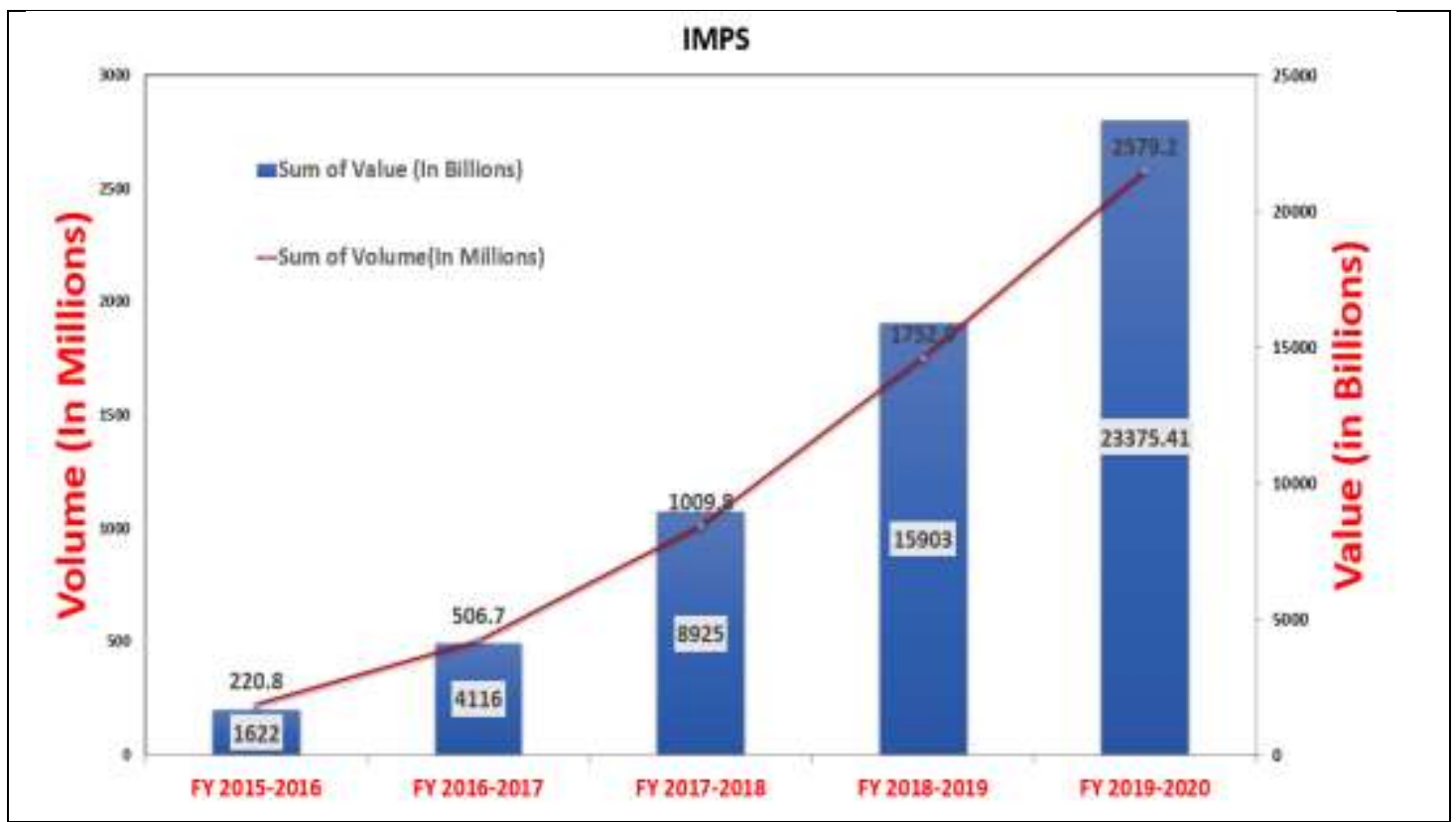

Data Source: RBI Payment System Indicators - Payment \& Settlement System Statistics

Fig. 10: IMPS Volume and Value

7.5 IMPS: Immediate payment service is a system where payment is done instantly in respect of interbank electronic fund transfer. Having known with bank a/c no. \& IFSC code money can be transferred from the sender bank to the beneficiary bank through mobile phones. This money transfer mechanism has started with the initiative of RBI and NPCI (national payment corporation of India) in 
2010 with the help of four banks, currently has grown up to 150+ banks. The highlighted feature of IMPS is it facilitates instant money transfer $\&$ is available $24 \times 7$, which is considered a great platform in case of emergencies (figure 10). A small nominal charge will be levied for the service. The transfer limit is restricted to Rs. 2 lakhs per day. It is available on the dual platform of mobile and the web. Once the payment is completed, multiple confirmations can be obtained so IMPS transactions are safe and secure while compared to physical transfer of funds \& all IMPS transactions are protected using the end-to-end encryptions on the internet. IMPS usage (in value terms) has shown a booming trend at a CAGR of $70.51 \%$ in 5years from 2015 to 2020 . The volume of IMPS has shown an upward trend from 220.8 million in FY 2015-2016 to 2579.2 million in FY 2019-2020, with a CAGR of 63.49\%.

7.6 Unified payment interface (UPI): The Government of India in association with RBI and Indian Banks started a new payment model called a Unified payment interface. It is introduced by the national payments corporation of India (NPCI) to promote a cashless society and mobile banking. It made online transfer easier than compared to a digital wallet or debit/credit card. It performs multiple bank functions like fund transfer and merchant payments with the help of a mobile application. Using the UPI app, a user can add all bank accounts with the hassle of remembering or even typing banking user ID or passwords. The information required for UPI-based transactions are the virtual payment address of the recipient and mobile banking PIN so that funds can be transferred, and money can be collected. It is a real-time interbank payment that allows both receiving money \& sending money. This can be done through UPI ID, mobile number, account no \& IFSC, Aadhar based, or using QR code. Any UPI app can be used for transfer \& payments of funds. Some of the UPI mobile applications are airtel thanks, BHIM, google pay, MI pay, jio pay, phone pay, amazon pay, WhatsApp pay, Samsung pay \& so on. UPI2.0 was introduced in Aug 2018 which came with an added feature that the user can link their overdraft accounts to a UPI handle. the advanced version of IMPS is now known as the Unified payment interface.

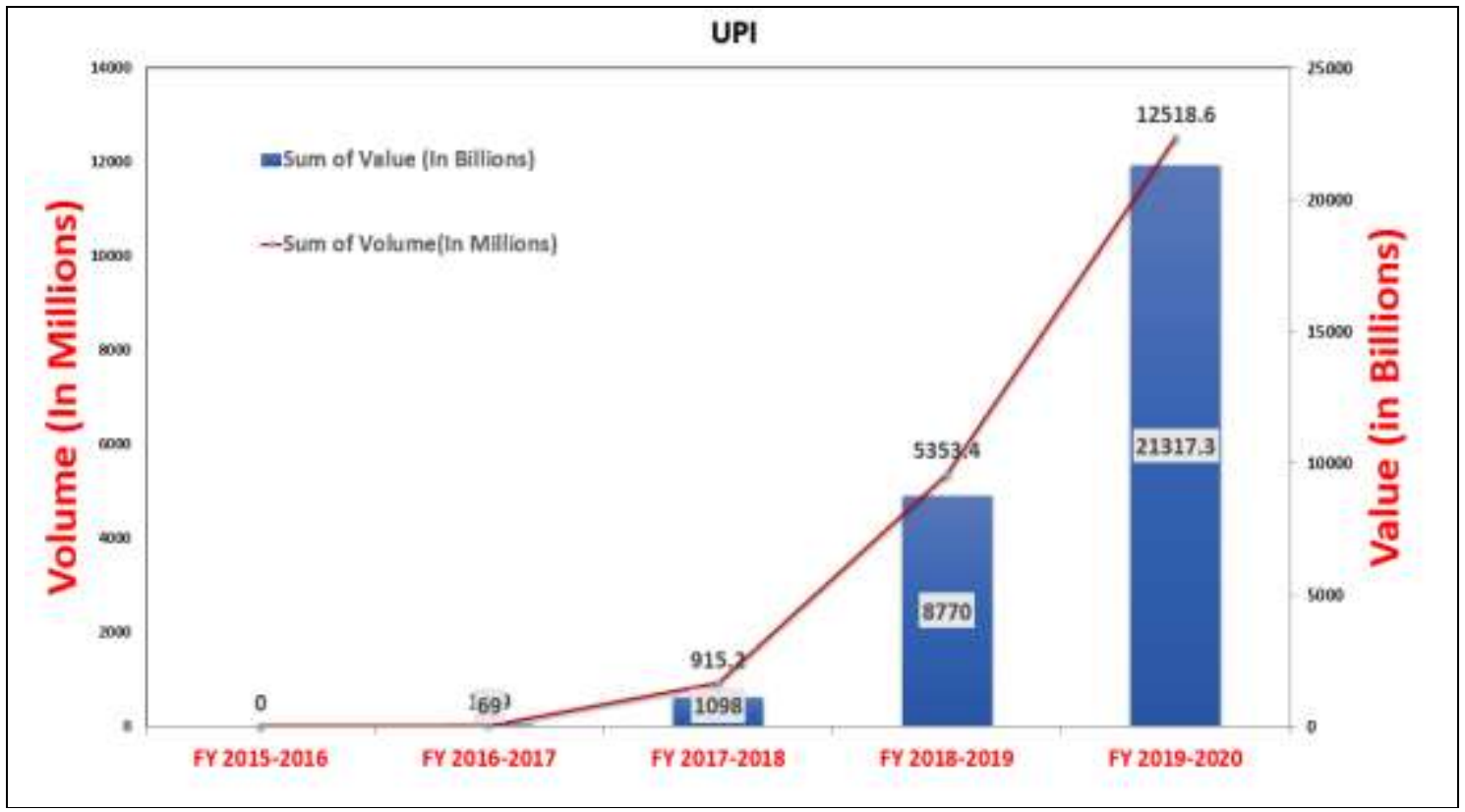

Data source: RBI Payment System Indicators - Payment \& Settlement System Statistics

Fig. 11: UPI Volume and Value

UPI usage (in value terms) has shown spectacular growth at a CAGR of $319.25 \%$ since inception in 2016UPI volumes have shown spectacular growth from million in FY 2016-2017 to 12518.6 million in FY 2019-2020, with a CAGR of $414.25 \%$ (figure 11).

\section{ABCD ANALYSIS OF THE DIGITAL INNOVATION IN BANKING SERVICES :}

Here is an effort to analyze the digital payment system of banks with the latest qualitative tool in Business management called $\mathrm{ABCD}$ analysis, in which $\mathrm{A}=$ Advantages, $\mathrm{B}=$ Benefits, $\mathrm{C}=$ Constrains 
$\mathrm{D}=$ Disadvantage. [15-20].

8.1 Advantages by using digital payments:

1. Digital elements helped to reduce cash transactions in the economy.

2. It has become a more popular mode of payment among younger generations.

3. Staying in any corner of the world, payment can be done within a short period.

4. Mobile banking is more useful in rural areas as it does not require long-distance traveling.

5. Tedious work of tax filing can be done with the help of digital banking.

\subsection{Benefits of using digital payments:}

1. It helps in prompt payment of bills due by the customer on time through alert messages from the apps \& emails, which saves from paying penalty.

2. The overall operating cost of the banks has been reduced.

3. More convenient for working-class people as well as elderly people as they carry out banking from their place of residence.

4. Consumers benefit from digital payment from the ease of convenience in making payments as compared to the cumbersome process of handling cash.

5. It saves consumers from losing cash from theft or robbery.

6. Consumers also benefit from digital payments over traditional paper-based cheques systems, since digital payments are instant, compared to the depositing cheque and collection process.

\subsection{Constraints of using digital payments:}

1. The lack of knowledge about computers and the use of the internet is a challenging task in digital payments.

2. The complexity involved in the operation of payments applications \& smartphone usage.

3. Due to the chances of fraud involved, the fear factor among customers to the usage of digital banking.

4. Lower broadband connectivity penetration rates in small towns \& cities demotivate the user to go for digital banking.

\subsection{Disadvantages of using digital payments:}

1. There is a chance of people losing employment as transactions are becoming more digital, fewer people are required to handle the job.

2. People have the chance of losing money due to fraud risk, fake apps \& websites.

3. Most of the customers stay away from digital payments due to security concerns.

4. The scope of services is limited in digital payments though many services are provided, opening bank $\mathrm{a} / \mathrm{c}$ and applying for a loan has to be done in the bank itself.

\section{RECOMMENDATIONS :}

From the detailed analysis of the concept of the digital payment system of banks, we can understand the benefits for the customers as well as to the banking sector. To make it user-friendly complexity is involved in the operation of various applications linked to digital payments. Reducing the transaction cost involved in digital payments to stand favorable in comparison to cash payments. There is a need to incentivize the vendors so that they more open to accepting digital payments in their day-to-day transactions. It will help to reduce tax evasion by the people\& increase revenue to the government. This makes Indian banks operate more confidently with modern banks of the world.

\section{CONCLUSION :}

The traditional banking system was only restricted to acceptance of deposits and lending of funds as their core banking business. As the decade passed innovation started taking place in the banking field along with other industries. This transformation results in technology-led disruption, convergence, and data analytics, etc. These forces are driving dramatic changes and reshaping the banking industry. Digital transformation made banking institutions act upon technology \& market trend to provide a more hassle-free \& engaging customer experience. The initiative of the government by introducing Digital India \& increased use of mobile and internet are the reasons for the fast-growing demand for digital payment. Digital payments play a pivotal role in banking along with the economy as it is contributing to the GDP of the nation. Almost all payments mechanism has shown a phenomenal increase in volume and value prospect. There are diverse factors including simple usage, the merits of digital payments, accessibility, the fast-growing smartphone penetration, favorable policies of regulation, and growing 
consumer readiness to the digital payment platform resulted in epidemic growth of the Indian digital payment system. Still, cash is the king in the Indian economy as the ratio of currency circulation to GDP $(\%)$ is exceptionally high at $11.2 \%$. There has been significant thrust on boosting digital payment in India during the last 5 years to make it a cashless economy. Due to the easy availability, smooth usage, accepted universally Cash is playing a significant role in payments. It has the added advantage of less consumer cost and no requirement of KYC. As banks are the major contributors to the financial services of the country, they have started the initial thrust, development of digital payments infrastructure and systems. They are driving towards growth by focusing on transforming business lines, channels, and products with maintaining the balance of continued regulatory measures and the growing threat of disintermediation. By balanced execution of tactical initiatives \& long-term transformational growth strategies, Banks are digitally becoming a successful sector in the world.

\section{REFERENCES :}

[1] Anitha, K. (2019). A Study on Challenges and Opportunities in E-Banking Sector in India. Shanlax International Journal of Commerce, 7(3), 14-17.

[2] Srikanth Charandas \& Nitesh Panch (2017). Literature review on related benefits of digital transactions. International journal of research in economics \& social sciences (IJRESS), 7(4), 115124.

[3] Gaonkar, D. S. (2018). Moving Towards Cashless India. SANSMARAN Management Research Journal, 8(1), 10-16.

[4] Dinesh, T. K. (2018). Demonetization and its Effects on Digital Payments. Economic Affairs, 63(2), 407-411.

[5] Rakesh N, et al. (2018). UPI: The Growth of the Cashless Economy in India. Arabian Journal of Business and Management Review (Oman Chapter), Special Issue, 36-40, DOI: $10.12816 / 0044903$.

[6] Shilza \& Madhulika, P. Sarkar (2019). The literature review on the adoption of the digital payment system. Global journal of an information system,11(3), 62-67.

[7] Pardhasaradhi Madasu (2015). India's Progress Towards Cashless economy-An Assessment. Savasana Journal of management, 7(2), 34-47.

[8] Kumari, N. \& Khanna (2017). Cashless payment: A Behavioral change to Economic Growth. International Journal of Scientific Research in Education, 5(7), 6701-6710.

[9] An overview of the Banking industry. https://www.investindia.gov.in/sector/bfsi-banking/overview of banking. Accessed on 15/12/2020.

[10] Nalla Bala Kalyan (2017). Banking sector reforms in India. International journal of management \& humanities, 4(4), 13-18.

[11] Raghavendra Nayak (2018). A conceptual study on digitalizing of banking issues \& challenges in Rural India, 8(6), 186-191.

[12] Jyoti Suraj Harshika (2018). Digitization in the banking sector. International journal of the trend in scientific research \& development (IJJSRD), Special Issue, 103-109. https://www.ijtsrd.com/papers/ijtsrd18681.pdf

[13] Santiago Carbo Valverde, (2017). The impact of digitalization on banking \& financial stability, Journal of Financial Management, Markets and Institutions, 5(1), 133-140.

[14] Keshav Lengare (2014). Banking industry of India \& recent trends. Golden research thoughts, 4(4), 1-5.

[15] Shailashri V. T. and Kariappa Anumesh (2020). Social Engagement: A means to Brand Building. International Journal of Case Studies in Business, IT, and Education (IGCSE), 4(2), 212-219.

[16] Aithal, P. S. \& Suresh Kumar, P. M., (2016). ABC Model of Research Productivity and Higher Educational Institutional Ranking. International Journal of Education and Management 
Engineering (IJEME), 6(6), 74-84.

[17] Aithal, P. S., Shailashree, V. T. \& Suresh Kumar, P. M. (2016). Analysis of NAAC Accreditation System using $\mathrm{ABCD}$ framework. International Journal of Management, IT, and Engineering (IJMIE), 6(1), 30-44.

[18] Aithal, P. S., Shailashree, V. T. \& Suresh Kumar, P. M., (2016). Analysis of ABC Model of Annual Research Productivity using ABCD Framework. International Journal of Current Research and Modern Education (IJCRME), 1(1), 846-858.

[19] Aithal, P. S., Shailashree, V. T. \& Suresh Kumar, P. M. (2016). Application of ABCD Analysis Framework on Private University System in India. International Journal of Management Sciences and Business Research (IJMSBR), 5(4), 159-170.

[20] Analysis of banking Reports-

https://www.rbi.org.in/scripts/AnnualReportPublications.aspx?Id=1209 Accessed on 26/12/2020.

$* * * * * * * * * * * *$ 